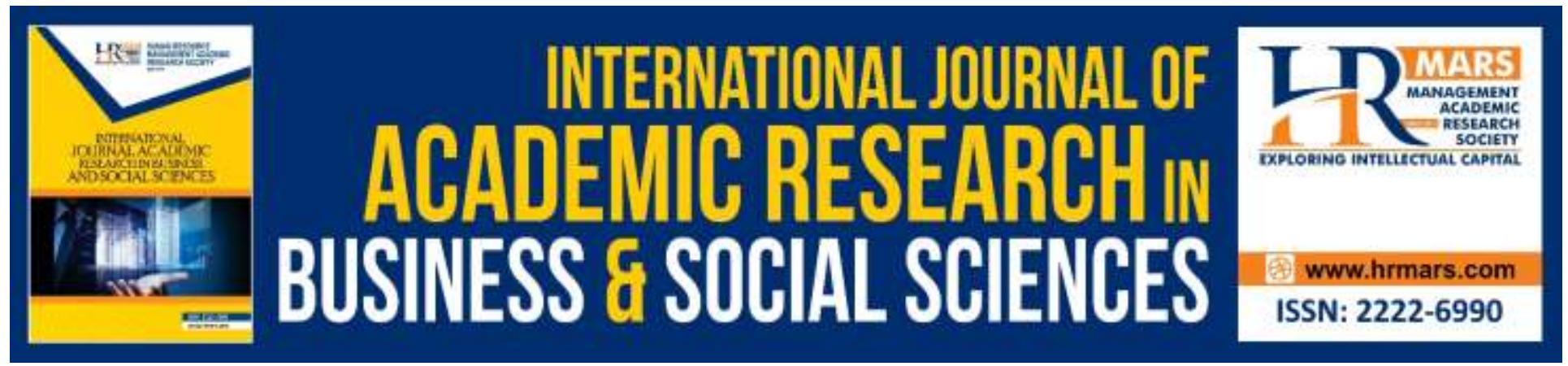

\title{
The Antecedents of Waqif's Loyalty in Cash Waqf from the Individual Perspective
}

Intan Fatimah Anwar, Syadiyah Abdul Shukor, Nuradli Ridzwan Shah Mohd Dali, Muhamad Azrin Nazri

To Link this Article: http://dx.doi.org/10.6007/IJARBSS/v9-i11/6651

DOI: 10.6007/IJARBSS/v9-i11/6651

Received: 13 October 2019, Revised: 26 October 2019, Accepted: 08 November 2019

Published Online: 23 November 2019

In-Text Citation: (Anwar, Shukor, Dali, \& Nazri, 2019)

To Cite this Article: Anwar, I. F., Shukor, S. A., Dali, N. R. S. M., \& Nazri, M. A. (2019). The Antecedents of Waqif's Loyalty in Cash Waqf from the Individual Perspective. International Journal of Academic Research in Business and Social Sciences, 9(11), 1228-1236.

Copyright: (C) 2019 The Author(s)

Published by Human Resource Management Academic Research Society (www.hrmars.com)

This article is published under the Creative Commons Attribution (CC BY 4.0) license. Anyone may reproduce, distribute, translate and create derivative works of this article (for both commercial and non-commercial purposes), subject to full attribution to the original publication and authors. The full terms of this license may be seen

at: http://creativecommons.org/licences/by/4.0/legalcode

Vol. 9, No. 11, 2019, Pg. 1228 - 1236

http://hrmars.com/index.php/pages/detail/IJARBSS

JOURNAL HOMEPAGE

Full Terms \& Conditions of access and use can be found at http://hrmars.com/index.php/pages/detail/publication-ethics 


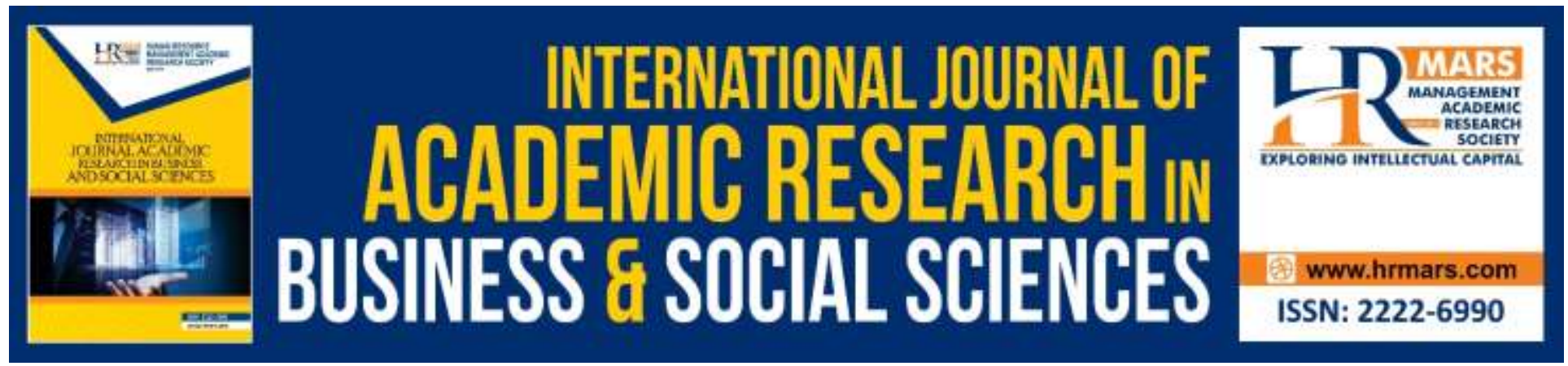

\title{
The Antecedents of Waqif's Loyalty in Cash Waqf from the Individual Perspective
}

\author{
Intan Fatimah Anwar, Syadiyah Abdul Shukor, Nuradli Ridzwan \\ Shah Mohd Dali, Muhamad Azrin Nazri
}

Faculty of Economics and Muamalat, Universiti Sains Islam Malaysia

\begin{abstract}
Waqf, defined as a piece of property that been preserved for benevolent and altruism purposes is one of the Islamic instruments that plays a significant role in the socio-economic sector to many of the Islamic countries. There are many types of waqf and one of them is cash waqf or waqf share. Cash waqf involves a sum of money or in a form of shares which is endowed by waqifs and handled by the waqf institution who its role is to assist benevolent causes and projects for community. In Malaysia, cash waqf is seen to have potential to be developed and promoted due to factors such as flexibility, convenience and speed to gain collection in funding waqf projects. Hence, this study aims to investigate antecedents of loyalty in cash waqf from the waqifs' perspective. This conceptual paper reviews literature related to waqifs internal attributes towards loyalty in cash. Based on the literature, it is proposed that waqifs' internal attribute towards loyalty in cash waqf is influenced by attitude, knowledge and experience that will helps to encourage repetitive endowment by waqifs.
\end{abstract}

Keywords: Waqf Endowment, Cash Waqf, Waqif, Individual Perspective And Loyalty.

\section{Introduction}

Waqf as one of the Islamic instruments plays a significant role to many of the Islamic countries including Malaysia in the socio-economic development sector. Defined with altruism intention as a piece of property that been preserved for specific purposes and able to serve numerous benefits not only to Islam community but to the whole country. However, the classical concept of waqf only focusing on the form of fix asset such as land or building has hindered its role as the catalyst to the economy system. Although the purpose of its two characteristics which are perpetuity and inalienability supposedly to guard the asset and to preserve the dedication of waqf but the illiquidity of waqf properties makes the institutions of waqf cashless, thus facing the problem in developing and maintaining the asset (Iman \& Mohammad, 2014; Zarqa, 1994; Shbeilat, Harasees, 2018). More than 70 percent of the total acreage from a large portion of waqf 
land in Malaysia are still undeveloped and this problem was similar in all states in Malaysia due to the slow progress (Kamaruddin, 1992).

Other than that, among the problem that have been highlighted by the past literature in developing waqf asset are such as lack of proper planning, management, funding, technical expertise, staff, coordination, efficiency, effectiveness and vision (Kamaruddin, 1992; Salleh, 2004). Thus, the administrative system, management and legislative institution of waqf, need to change the evolution of waqf method where the original concept of waqf which involving a permanent property need to be shifted to the concept of movable property (Raissouni, 2001) such as cash waqf or waqf share.

\section{Waqf}

Although the term of waqf is not directly mentioned in the Al-Quran and Hadith, but the majority of jurist has interpreted the meaning of waqf as a sadaqah jariah or alms giving which is also called as al-sadaqah al-muharramah that aims to benefit the heirs or general welfare (Mustaffa \& Muda, 2014). This meaning according to the Figh jurist is similar to the word 'alhabs' which means to 'stop' or to 'hold' while from syarak perspective, waqf has been defined as of holding certain property and preserving it for the confined benefit of certain philanthropy and prohibiting any use or disposition of it outside that specific objective and this implies to a nonperishable property whose benefit can be extracted without consuming the property itself (Kahf, 2003). The definition of waqf by Kahf covers the traditional concept of waqf asset where he emphasizes on the idea of abstention from consumption of the asset in order to keep it available for repeated extraction of its usufruct (Iman \& Mohammad, 2014). While in the new waqf concept, contemporary jurist has agreed for the replacement of the perpetuity of object with the perpetuity of dedication by assigning value to the object of waqf and then amortizing it thereby by-passing the perpetuity and inalienability of the object which led to the acceptance of cash waqf and istibdal (Iman \& Mohamad, 2014; Kahf, 1999).

\section{Cash Waqf}

One of the types of waqf which movable property has known as cash waqf or waqf share. This type of waqf have been implemented during the Uthmaniyyah ruling in Turkey since in the early 15th century (Pamuk, 2000; Kuran, 2010; Razali Othman, 2015). Cash waqf involves a sum of money or in a form of shares which is endowed by waqifs and handled by the waqf institution who its role is to assist benevolent causes and projects for community. Cash waqf is seen to have potential to be developed and promoted due to factors such as flexibility, convenience and speed to gain collection in funding waqf projects. This new concept of waqf enable people to perform waqf in various innovative and creative channel (Manat, 2007) besides helping the waqf managers to develop and venturing the waqf fund into the activities that can provide with the hinger returns (Ahmad, 2007). Moreover, Zakaria and Muda (2015) revealed, despite having Muslim as a majority population in Malaysia, but it is sad that ownership in terms of land and building are little by them. Through the implementation of cash waqf, Muslim can now own a building such as house or commercial property by developing the waqf land. Cash waqf is also 
INTERNATIONAL JOURNAL OF ACADEMIC RESEARCH IN BUSINESS AND SOCIAL SCIENCES

Vol. 9, No. 11, November, 2019, E-ISSN: 2222-6990 @ 2019 HRMARS

seen as an important source of financing for the development of economy, social services, religion, education and healthcare facilities (Othman, 2015).

\section{The Antecedents of Loyalty in Cash Waqf}

Loyalty dependably be related in the field of marketing as a basic component for organizations to design their marketing strategy mainly on promotional technique in order to retain existing customers (Kotler \& Armstrong, 2018). Principally, organizations' profit is resulted by loyalty measurement of their loyal customers. Therefore, it is crucial to understand the repetitive buying behavior from customers retention of a same brand, product or services (Jr, Omar, \& Wahid, 2007). Kotler and Armstrong (2018) stated that loyalty from marketing perspective should be particularly dynamic for a new to market offering and rewarding to existing product brand. However, the benefit of consumer's purchase intentions can only be realized by a company when the consumers start to purchase the service or product. In addition, consumers' loyalty or repurchase intention is not the only variable of interest for the service provider. But also, resulted as behavioral outcome that can be clearly explained from quantity of purchase by the customers (Chatterjee et al., 2018).

Hence, in cash waqf context, loyalty can be a measure from repetitive contribution of the waqifs. Nevertheless, it is essential to study on the factors contribute to repetitive contribution which might leads to loyalty in cash waqf.

\section{Attitude as an Antecedent}

Attitude is an important concept to be studied in consumer behaviour as it is significant to the customer loyalty (Evanschitzky et al., 2012). In fact, Johnson and Huber (2006) stated loyalty is due to affective attitudes that mediate the effects of performance perceptions on intentions over time. Zeithaml, Berry, and Parasuraman (1996) added that two items used to measure loyalty are consumers' intention to repurchase or repetitive in buying and their willingness to recommend the product. Moreover, Teah, Min and Lwin, M. (2014) proved that it is an evident to conclude that the motivation to donate in charities can be influenced by attitude. Previous studies have mentioned, the intention of behavioral can be affected by attitude as one of the contributing factors for cash waqf acceptance (Osman et al., 2014; Shukor et al., 2015). Another study also revealed that attitude of Muslim employees in contributing to cash waqf which based on their income was found to have significant influence on the behavioural intentions (Pitchay et al., 2015). Thus, it is believed that positive attitude of behavioural intention can resulted to satisfied customer which likely lead to loyalty behaviour, for example, repeat purchase and willingness to give positive word of mouth (Jr et al., 2007). Subsequently, it is expected that attitude of the individual can motivate the action of waqifs. Thus, it is expected that:

H1: There is a significant relationship between attitude of waqifs and cash waqf loyalty. 


\section{Knowledge as an Antecedent}

Knowledge on products and services is very crucial to be acquired by customers to decide on their decision making in buying specially in facing with challenge of market development and evolution (Ballantyne et al., 2006). Similar to cash waqf, waqifs must have knowledge at least to understand the objectives and benefits of the contribution. In recent studies found the impact of knowledge is significant to determine waqif's trust towards the waqf institution (Osman, 2014; Shukor et al., 2015). However, this knowledge needs to be enhanced by individuals particularly waqifs so that the cash waqf can be crucially understood as one of the vital factors for the waqf instrument growth and its huge role for ummah (Othman, 2015). On the other hand, there are still many problems arising from lack of knowledge among individual and the Islamic society which has contributed to mismanagement and corruption in many of the waqf institutions (Ibrahim \& Ibrahim, 2013). It is expected that an individual and waqifs with more knowledge on cash waqf will have impact on cash waqf contribution. This leads to the following hypothesis:

H2: There is a significant relationship between knowledge of waqifs and cash waqf loyalty.

\section{Experience as an Antecedent}

Another factor that will expected to the significant of loyalty in cash waqf is experience which is substantial to be considered in purchase decision making. In moat studies of a decision making, almost focused on new decisions and neglected the importance of experience (Salarzehi et al., 2010). Whereas, experience in repeat purchase or even re-donate has positive impact on customers purchase decision making (Aly et al., 2017). Since organizations valued customer loyalty, therefore, customer experience is assumed as one of the intangible assets for organizations of their lifetime brand value (Mascarenhas et al., 2006). In the context of waqf, experience of waqf in the Islamic countries has been shown that benefice can achieve many incredible achievements and performances related to social role for the ummah and community development in long run for example, it helps in the development of urban services, education and health (Salarzehi et al., 2010). In addition to cash waqf, waqifs experience the act to endow in cash waqf through various channels for instance, their contribution via online banking transaction, salary deduction, shares and cash at hands. These various convenience experiences faced by waqifs will helps to increase the consistency of endowment which resulted to loyalty in the future. Consequently, it is hypothesized that:

H3: There is a significant relationship between experience of waqifs and cash waqf loyalty.

\section{The Proposed Conceptual Framework}

This study intends to examine the antecedents of loyalty in cash waqf endowment from the individual perspective which refers to waqif as an individual. The antecedents of loyalty in cash waqf includes knowledge, experience and attitude. The hypotheses are developed to examine the relationships between each antecedent with the cash waqf loyalty. Figure below explains the suggested conceptual framework of this study. 


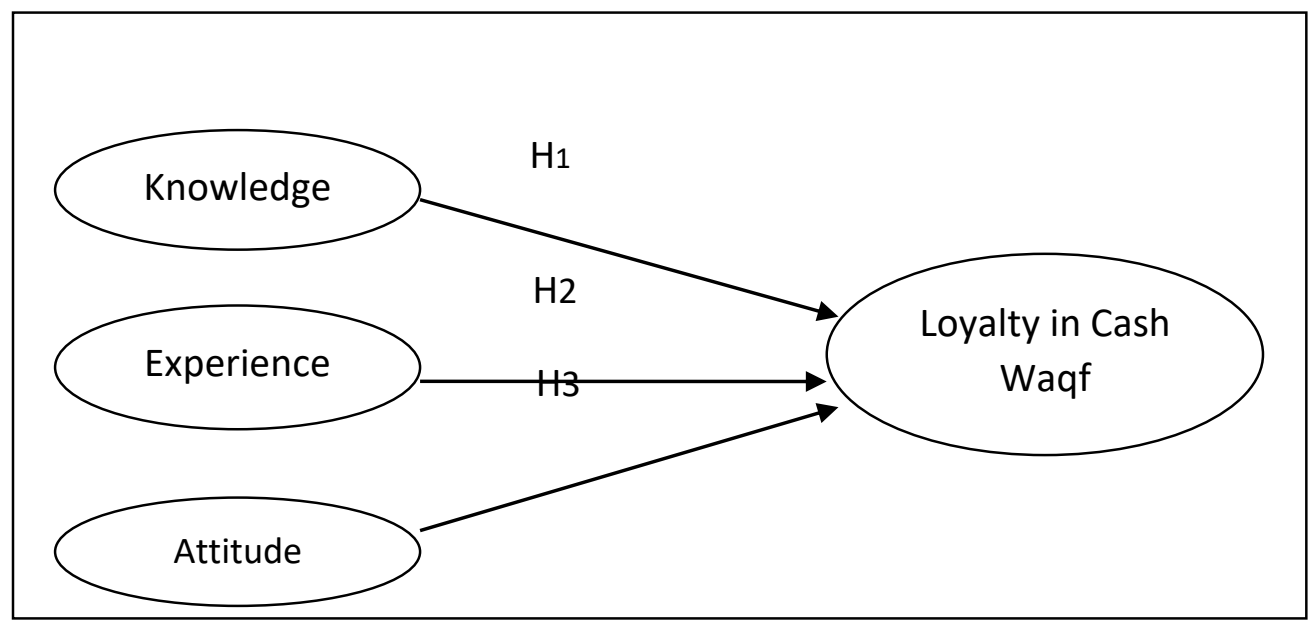

\section{Figure 1: The Proposed Conceptual Framework of Study}

\section{Methodology}

This study employed quatitative research method as it aims to explore the antecedents of waqifs' loyalty on cash waqf. The antecedents are all related to personal and behavioral of waqifs such as their attitude, knowledge and experience. A total number of 300 sets of questionnaires will be distributed to individuals who are waqifs and have been identified consistently contribute to cash waqf. These waqifs will be selected from the central region of Malaysia that consists Kuala Lumpur, Selangor and Negeri Sembilan. This is due to the highest density population especially the working age which between 16 to 64 (statistical data provided by the Department of Statistics Malaysia). It is expected that waqifs will be derived among working age of population who generally have income to be willing to contribute in cash waqf. Once data for present study is collected, analysis will be done using Structural Equation Modelling (SEM). This statistical analysis is chosen because it estimates interrelated dependence relationships in a single model, it can represent unobserved concepts in these relationships and it is able to correct for measurement error in the estimation process (Hair et al., 2017, Kline, 1998 and Byrne, 2010). In addition, SEM allows the researcher to validate the measurement model before making any attempt to evaluate the structural model (Hair et al., 2017).

\section{Conclusion}

This paper is based on an ongoing study which intends to investigate antecedents of loyalty in cash waqf endowment from the perspective of waqif's personal and behavioral factors. The antecedents have been identified from the literature as attitude, experience and knowledge of waqifs. These antecedents are expected to develop consistency and repetitive giving behavior in cash waqf which lead to loyalty in cash waqf endowment. It is clearly understand that the 
antecedents derived from the waqis's personal and behavioral factors toward loyalty in cash waqf will be able to encourage Muslim who is the largest population in Malaysia to consistently participate in cash waqf. Besides that, this study contributes to the area of marketing particularly consumer behavior. Finally, it is hope that this study will contribute to the waqf institutions in designing their effective promotional program and strategies for cash waqf to individual Muslims or potential waqifs in the future.

\section{References}

Ahmad, H. Z. Z. (2007). Cabaran dalam mempertingkatkan potensi pembangunan tanah wakaf. Jurnal Pengurusan JWZH, 1(1), 1-12.

Aly, B. H., Elaref, N., \& Yacout, O. M. (2017). A literature review and a conceptual framework of the brand personality in not-for profit organizations, 8(5), 201-213.

Ballantyne, R., Warren, A., \& Nobbs, K. (2006). The evolution of brand choice. Journal of Brand Management, 3(4), 339-352.

Byrne, B. M. (2010). Structural equation modeling with AMOS: Basic concept application and programming. London: Lawrence Erlbaum Associates.

Chatterjee, S., G, S., \& Sravanan, C. N. S. (2018). Does Intention Translate into Action? Investigating the Impact of Loyalty Intention on Future Usage. Journal of Indian Business Research.

Evanschitzky, H., Ramaseshan, B., Woisetschläger, D. M., Richelsen, V., Blut, M., \& Backhaus, C. (2012). Consequences of customer loyalty to the loyalty program and to the company. Journal of the Academy of Marketing Science, 40(5), 625-638.

Hair, J. F., Hult, G. T. M., Ringle, C. M., \& Sarstedt, M. (2017). A Primer on Partial Least Squares Structural Equation Modeling (PLS-SEM).

Ibrahim, D., \& Ibrahim, H. (2013). Revitalization of Islamic Trust Institutions Through Corporate Waqf. 4th International Conference on Business and Economic Research (4Th Icber 2013), (March), 192-202.

Iman, A. H. M., \& Mohamad, M. T. S. (2014). Waqf property: Concept, management, development, and financing. Penerbit UTM Press.

Johnson, M. D., Herrmann, A., \& Huber, F. (2006). The Evolution of Loyalty Intentions. Journal of Marketing, 70(2), 122-132.

Jr, S. L. S., Omar, M. W., \& Wahid, N. A. (2007). The effect of brand image on overall satisfaction and loyalty intention in the context of color cosmetic. Asian Academy of Management, 12(1), 83-107.

Kuran, T. (2010). The scale of entrepreneurship in Middle Eastern history: Inhibitive roles of Islamic institutions. The Invention of Enterprise: Entrepreneurship from Ancient Mesopotamia to Modern Times, 62-87.

Kahf, M. (2003, January). The role of waqf in improving the ummah welfare. In International Seminar on Waqf as a Private Legal Body (pp. 6-7).

Kahf, M. (1999). Financing the development of awqaf property. American Journal of Islamic Social Sciences, 16(4), 39-68. 
INTERNATIONAL JOURNAL OF ACADEMIC RESEARCH IN BUSINESS AND SOCIAL SCIENCES

Vol. 9, No. 11, November, 2019, E-ISSN: 2222-6990 @ 2019 HRMARS

Kamaruddin, N. (1992). Isu pembangunan tanah wakaf di Malaysia. Kuala Lumpur: Dewan Bahasa dan Pustaka.

Kline, R. B. (1998). Software review: Software programs for structural equation modeling: Amos, EQS, and LISREL. Journal of psychoeducational assessment, 16(4), 343-364.

Kotler, P. T., \& Amstrong, G. (2018). Principles of Marketing. $17^{\text {th }}$ Ed. Hoboken: Pearson Higher Education.

Manat, A. B. (2007). Isu-isu semasa berhubung pembangunan tanah wakaf. Jurnal Pengurusan JWZH, 1(1), 53-71.

Mascarenhas, O. A., Kesavan, R., \& Bernacchi, M. (2006). Lasting customer loyalty: a total customer experience approach. Journal of Consumer Marketing, 23(7), 397-405.

M'mbijiwe, J. M., Jagero, N., Mburugu, B. M., \& Barchok, H. K. (2018). Relationship between Teacher Training Practices and Transition to Secondary School for Public Primary School Learners with Disabilities in Meru County, Kenya. International Journal of Academic Research in Progressive Education and Development, 7(2), 64-71.

Mustaffa, N., \& Muda, M. Z. (2014). Pengurusan wakaf pendidikan di institusi pengajian tinggi Malaysia: Satu sorotan literatur. International Journal of Islamic and Civilizational Studies (IJMS), 21(2), 63-81.

Osman, A. F. (2014). An Analysis of Cash Waqf Participation Among Young. In 9th International Academic Conference (pp. 572-584).

Pamuk, S. (2000). A monetary history of the Ottoman Empire. Cambridge University Press.

Pitchay, A. A., Meera, A. K. M., \& Saleem, M. Y. (2015). Factors influencing the behavioral intentions of muslim employees to contribute to cash-waqf through salary deductions. Jornal of King Abdulaziz University, Islamic Economics, 28(1), 63-100.

Othman, R. (2015) Wakaf Tunai: Sejarah, Amalan dan Cabaran Masa Kini. Dewan Bahasa dan Pustaka. Kuala Lumpur.

Raissouni, A. (2001). Islamic" Waqf Endowment": Scope and Implications. ISESCO.

Salarzehi, H., Armesh, H., \& Nikbin, D. (2010). Waqf as a Social Entrepreneurship Model in Islam. International Journal of Business and Management, 5(7).

Shbeilat, M. K., Al Harasees, M. N. (2018). Do Listed Companies Need an IFRS Committee Beside Audit Committee? International Journal of Academic Research in Accounting, Finance and Management Sciences 8 (2): 8-18.

Salleh, B. (2004). Pembangunan Semula Tanah Wakaf Lambat. Utusan Malaysia, $15^{\text {th }}$ June.

Shukor, S. A., Anwar, I. F., Sabri, H., Aziz, S. A., \& Ariffin, A. R. M. (2014). Giving Behaviour: Who Donates Cash Waqf ? Malaysian Journal Of Consumer And Family Economics Giving, 87100.

Teah, Min., \& Lwin, M. (2014). Moderating role of religious beliefs on attitudes towards charities and motivation to donate. Asia Pasific Journal of Marketing and Logistics, 26(5), 738760.

Zakaria, M. S., \& Muda, M. Z. (2015). Pelaksanaan Wakaf Tunai di Malaysia: Satu Sorotan Literatur. Prosiding Kolokium Antarabangsa Siawazah Pengajian Islam, 44-50.

Zarqa, M. (1994). Financing and investment in Awqaf projects: A non-technical introduction. 
Zeithaml, V. A., Berry, L. L., \& Parasuraman, A. (1996). The behavioral consequences of service quality. Journal of Marketing, 60(2), 31-46.

\section{Corresponding Author}

Intan Fatimah Binti Anwar

Faculty of Economics and Muamalat

Universiti Sains Islam Malaysia (USIM)

Malaysia

Email: intan.anwar@usim.edu.my 